\title{
Finnish and Portuguese Parents' Perspectives on the Role of Teachers in Parent-Teacher Partnerships and Parental Engagement
}

\author{
Cristiana Levinthal ${ }^{1, * \mathbb{D}}$, Elina Kuusisto ${ }^{2} \mathbb{D}$ and Kirsi Tirri ${ }^{1} \mathbb{D}$ \\ 1 Department of Educational Sciences, University of Helsinki, 00100 Helsinki, Finland; kirsi.tirri@helsinki.fi \\ 2 Faculty of Education and Culture, Tampere University, 33100 Tampere, Finland; elina.kuusisto@tuni.fi \\ * Correspondence: cristiana.levinthal@helsinki.fi
}

Citation: Levinthal, C.; Kuusisto, E.; Tirri, K. Finnish and Portuguese

Parents' Perspectives on the Role of Teachers in Parent-Teacher Partnerships and Parental Engagement. Educ. Sci. 2021, 11, 306. https://doi.org/10.3390/

educsci11060306

Academic Editor: James Albright

Received: 16 April 2021

Accepted: 16 June 2021

Published: 21 June 2021

Publisher's Note: MDPI stays neutral with regard to jurisdictional claims in published maps and institutional affiliations.

Copyright: (c) 2021 by the authors. Licensee MDPI, Basel, Switzerland. This article is an open access article distributed under the terms and conditions of the Creative Commons Attribution (CC BY) license (https:/ / creativecommons.org/licenses/by/ $4.0 /)$.

\begin{abstract}
The current educational reforms in Finland and Portugal require a holistic engagement of parents with learning, bringing parents and teachers together as partners. This qualitative study, which interviewed Finnish $(\mathrm{N}=10)$ and Portuguese $(\mathrm{N}=9)$ parents, aimed to explore parents' views on the role of teachers in supporting parent-teacher partnerships and parental engagement with the school. Inductive content analysis was performed to analyze the interviews. From a general standpoint, three patterns were found in the parents' narratives about the role of teachers in supporting partnership and engagement: communication, professionalism, and invitations to active parental participation. From a cross-cultural standpoint, Finnish parents evidenced partnerships and engagement grounded in little face-to-face contact but consistent online communication with the teacher, as well as trust in their professionalism and independent work. The Portuguese parents revealed rather frequent active participation within the school premises, more recurrent face-to-face communication with the teacher, and appreciation for teachers' timely responses and support. Recommendations for a holistic approach of engagement and partnerships were brought forward within the context of teacher education, such as the need to maintain simple but regular communication with parents and the relevance of reconsidering the frequency of parental activities in the school.
\end{abstract}

Keywords: parents' perspectives; teachers' support; parent-teacher partnerships; parental engagement; Finland; Portugal

\section{Introduction}

\subsection{Parent-Teacher Partnerships and Parental Engagement}

The positive influence of parental engagement in education on children's learning and achievement is universally acknowledged [1,2]. However, parental engagement is dependent on effective parent-teacher partnerships and on teachers' support for engagement [1]. Traditionally, the parental role has been constructed as more reactive than active [3,4]. However, current educational aims for a holistic pedagogy [5] call for the urgent activation of parents' full potential to partner with teachers in order to promote the education of the whole person. The aim of this article is to explore parents' perspectives on the role of teachers in supporting parent-teacher partnerships and parental engagement in school, in pedagogically holistic school contexts.

Parents' engagement in education is a multidimensional construct encompassing a variety of perspectives and definitions [6,7]. Nevertheless, it has traditionally been studied based on a school-centered approach, that is, focused on parents' and families' assistance in satisfying school needs. In contrast to school-centered approaches, a holistic pedagogy not only seeks to teach content-related knowledge, such as math, science, or languages, but it also strives to help students develop a set of skills, values, and attitudes that will result in them becoming autonomous, proactive, and competent global citizens [5]. Holistic pedagogical schools are learning-centered, as opposed to school-centered, as they aim 
for the comprehensive development of the student. We propose that a learning-centered approach to parents is required for schools to achieve full success in holistic pedagogy. In this article, we adopt Janet Goodall's [1] contemporary learning-centered framework of parent-teacher partnerships and parental engagement.

From this perspective, different forms of parental engagement are acknowledged as important, providing they maintain the centrality of children's learning and are supported by a well-grounded parent-teacher partnership [1]. Although parental engagement and parent-teacher partnerships are not synonyms, the latter plays an important and indissociable role in the former. Being partners reflects the shared responsibilities parents and teachers carry out throughout children's schooling and learning paths [6]. It is only by allowing such shared roles, as opposed to separated or sequential roles, that parents can genuinely be engaged with learning. Partnerships are, therefore, grounded in collaboration towards the children's learning. According to Goodall, the key features of an effective and genuine partnership are that teachers and parents engage in dialogue around and with the learning of the child; teachers and parents value each other's knowledge and legitimate the authority of each other's roles; and teachers and parents participate in supporting learning (for a detailed description of the framework, see Authors) [8]. Research on partnership and engagement has evolved to legitimate a more active and empowered parental role $[1,6,7,9]$. However, the teacher, regarded as the reference actor within the classroom, has consistently been pointed out in studies as a central enabling figure of parental engagement [1,9]. The teacher's role in encouraging participation is to promote parents' engagement by suggesting activities or inviting meaningful participation in and outside the school $[10,11]$. For example, a parent-teacher meeting about a child's progress, parental homework support, or a parent and child reading a book together in the park are all activities that illustrate learning-centered parental engagement. The difference between these interactions is their context, i.e., whether they are school-, schooling-, or broadly learning-related [1]. Goodall underlines the importance of the latter, as it allows parents to engage with their children's learning in school-independent settings and to take advantage of the strengths of natural contexts. The teacher plays a preponderant role in supporting engagement in activities that are relevant to the student's broader learning as well as in cultivating the meaningfulness of such learning in school- and schooling-related engagement [11]. Such support is better conveyed through mutually respectful parent-teacher dialogue.

Communication is necessary in parent-teacher partnerships in order to align goals. Research on parents' perspectives shows that an open line of communication between parents and teachers is viewed as an important facilitator of partnership and engagement [12] and a primary way of enhancing parents' trust in the teacher [13]. Conversely, in the context of parental engagement in homework, a lack of communication has been shown to pose serious risks to partnerships, as parents' own role in construction and beliefs about such forms of involvement may differ from teachers' expectations [4].

Accordingly, Baker and colleagues [14,15] underline the importance of teachers and schools not only communicating but also actively listening to parents. Their focus-group research with parents and teachers revealed that parents may feel distant from the teacher if proper time is not allocated to invest in dialogue. Moreover, parents may experience anger or frustration when they perceive that their initiatives to increase home-school contact are not welcomed. A further qualitative study found that parents considered the following three teacher behaviors to be essential during dialogue: taking notes, discussing next steps, and showing attention and concern [16]. Such behaviors cause parents to feel listened to and valued as assets in their children's schooling and learning [13] and legitimate their role and participation.

Research demonstrates that teachers' invitations for participation may vary according to the structural framework provided by the school, and that such invitations constitute an important element in the construction of parents' roles and their motivation to be engaged [17]. Teachers' invitations for engagement can contribute significantly to the strengthening of partnerships if parents feel their participation is worthwhile. By contrast, 
studies have shown that merely visiting the school to receive a one-way report from a teacher on a child's behavior or achievement, or sitting down at home to teach homework, might negatively affect engagement and home-school partnerships $[7,18]$. Such a schoolcentered model of parental involvement poses several challenges for genuine parental engagement with learning. For parents, teachers' invitations to attend school activities might cause feelings of guilt if they are unable to do so [14], which might negatively affect the relationship with teachers.

Despite the importance of the teachers' active role in engaging parents in learning, research shows that partnering with parents and supporting their engagement is an area where teachers lack confidence and formal instruction $[19,20]$. The latest reports on teachers in Europe [21] show that 36 percent of teachers consider addressing parents' concerns to be a source of stress in their daily work. Studies on teacher training programs [16,22] have concluded that, in order to better facilitate children's learning, more formal instruction is required to improve the quality of teacher education regarding parent-teacher partnerships and to enhance communication with parents from diverse backgrounds. Indeed, research is calling progressively more attention to the gap between the importance teacher training programs give to the parental engagement topics and their lack of courses on the subject. These studies $[9,23]$ underline developing partnerships with parents as a core competence of a professional teacher and family engagement as an essential component of school organization.

In this article, we study parents' perspectives on the role of teachers in supporting parental engagement and partnerships, to inform on best practices in parent-teacher partnerships and parental engagement.

\subsection{Context of the study}

Finland and Portugal were selected for this study because both have recently introduced important curriculum reforms with holistic pedagogical aims [24,25]. However, Finland and Portugal are implementing these holistic educational goals from different historical and cultural backgrounds. While Portugal became independent in the 12th century and later endured a dictatorship, Finland's independence began just 104 years ago, and the country has been a constitutional democracy since its inception [26,27]. Nevertheless, today, in the sphere of education, both nations share many similarities through their membership of the European Union (EU), the Organization for Economic Cooperation and Development (OECD), and the Programme for International Student Assessment (PISA). Table 1 summarizes both countries' historical backgrounds and landmarks in basic education from the 1900 s to today. The early 20th century was chosen as the starting point to allow a more concise contextualization.

In Finland, the teaching profession and its socio-cultural background have grown in an iterative manner. The Lutheran moral values of Nordic societies formed the basis of teachers' roles grounded on ethics, hard-work, and independent thinking [28]. When sixyear compulsory public education was introduced in 1921, teachers were already important cultural actors, had received specific education in teacher training colleges, and bore the main responsibility for increasing literacy among boys and girls [29]. In 1943, Finland was the first country in the world to introduce a law on free meals for all students [30]. Quality education for all was supported by the basic principles of a trustworthy and stable social welfare system [31]. Pioneer reforms and policy decisions resulted in nine-year compulsory basic education, gradually realized over the 1970s [32], while a five-year master's degree became a prerequisite in academic teacher education in 1979 [29]. The decentralized nature of the new educational system granted teachers autonomy to influence decisions about teaching [29]. This enhanced their prestige and social trust, increasing the competitiveness and attractiveness of the profession [29,33]. 
Table 1. Finnish and Portuguese historical background and landmarks in basic education.

\begin{tabular}{|c|c|c|}
\hline & Finland & Portugal \\
\hline \multirow{5}{*}{$\begin{array}{l}\text { Early } \\
1900 s\end{array}$} & Lutheran value heritage; democracy & Catholic value heritage; dictatorship \\
\hline & Ethical, moral, and diligent teacher; & Conformist, obedient teacher; \\
\hline & Teaches literacy, develops cultural activities; & Teaches respect for the nation, family, and traditions; \\
\hline & Attends teacher-training college; & Receives limited or no specific training; \\
\hline & All children receive free education and meals in school. & Unprivileged children are absent or drop out of school. \\
\hline \multirow{5}{*}{$\begin{array}{l}\text { Late } \\
1900 \mathrm{~s}\end{array}$} & Social welfare system; teacher education reform & Rupture from the system; democracy \\
\hline & Trustworthy and stable society; & Revolution and rebirth of society; \\
\hline & Decentralized educational system; & Centralized educational system; \\
\hline & Teacher education establishes a 5-year master's degree; & Teacher education differs in length and institution type; \\
\hline & Teaching has high levels of attractiveness and prestige. & Teaching has low levels of attractiveness and prestige. \\
\hline \multirow{5}{*}{$\begin{array}{l}\text { Early } \\
2000 \text { s }\end{array}$} & International cooperation and policies & International cooperation and policies \\
\hline & Common European high standards in education; & Common European high standards in education; \\
\hline & Bologna Process: teachers' research-based education; & Bologna Process: mandatory 5-year master's degree; \\
\hline & PISA: Affirmation as a world reference in education; & PISA: Consistent educational growth and policy reforms; \\
\hline & Reform of the Core Curriculum for Basic Education. & Reform for a national student-centered approach. \\
\hline
\end{tabular}

Today, Finnish basic education encompasses the elementary (grades 1 to 6) and lower secondary levels (grades 7 to 9). Elementary school students have one main class teacher. Finland continues to pursue high standards in education, embedded in the context of growth and principles shared with the EU and international organizations such as the OECD. Moreover, compulsory education will be extended to twelve years starting in autumn 2021 [34]. Finnish education entrenched its position as a world reference for excellence in the first decades of the 21st century [35] through the PISA reports. Even though studies on upper secondary school students and pre-service teachers reveal a slight decrease in the attractiveness of the profession, teachers are still highly regarded by society and seen as ethical, autonomous, and reflective professionals [21]. Because the National Core Curriculum for Basic Education 2014 [25] serves the teacher as a general framework in terms of learning goals, core competences, and values [35], Finnish pre-service teachers must acquire a wide variety of skills for autonomy. Such skills include high levels of content and pedagogical knowledge; social, moral, and technological knowledge; skills for research, planning, organizing, and assessment; and skills for cooperation with other teachers and with parents $[35,36]$. The latest reform of the Core Curriculum was introduced for grades 1 to 9 between 2016 and 2019 [25]. The changes aim to improve the already holistic educational system by increasing rich interactions within the school culture and the integration of pupils' diverse learning contexts. The curriculum focuses on developing students' transferrable skills, such as thinking and learning to learn, cultural competence, interaction, participation, and managing daily life [25].

In Portugal, a long 41-year period of dictatorship shaped the development of education and the role of teachers in society. During that period (1933-1974), the compulsory education, of four years, reflected the fascist government's set of principles, grounded in devotion to the Catholic religion and national traditions. For boys, schooling concentrated on drawing skills and manual abilities, while the education of girls focused on domestic activities and respect for family values. Moreover, textbooks were stipulated by the government, and teacher training was limited or non-existent; absenteeism and drop out levels were high among less privileged children [26].

Major reforms in the organization of schooling and curricula were introduced after the revolution and the beginning of democracy, but it was not until the 1980s that fundamental change occurred $[37,38]$. The curriculum and teacher education were reformed and the pedagogical and social prestige of the teaching profession started to increase [26]. Besides expanding compulsory education to nine years, the reforms aimed to guarantee all children the right to education and culture, focusing on active citizenship, equality of opportunities, 
and freedom of learning and teaching $[37,38]$. From then until the first years of the 21st century, teacher education was nonetheless inconsistent and weakly regulated [39]. It varied from four to six years and could occur in universities, polytechnics or through less formal practical training [39].

Currently, Portuguese basic education is divided into three cycles. The first cycle refers to grades 1 to 4 , the second cycle to grades 5 and 6 , and the third cycle to grades 7 to 9 . During the first four years, students are taught by a main class teacher. Portugal continues to strive for high standards in education and teacher training, influenced by EU policies and OECD countries. In 1999, the Bologna Process triggered the establishment of a five-year Master's degree for all teachers [39], and, in 2009, compulsory education increased to twelve years [37]. Moreover, the role of teachers became more complex, as they were expected to acquire more autonomy and reflective skills [40]. Between 2000 and 2018, Portugal consistently improved its PISA ranking regarding students' reading, math, and science skills [37]. Between 2002 and 2015, Portuguese parliamentary debates on education centered on OECD, PISA, and other international results, as well as on educationally successful nations, such as Finland, Denmark, Sweden, Germany, and the UK [41].

In 2018, Portugal implemented a reform to introduce a student-centered approach to learning, based on the principles of holistic pedagogy [24] and to increase the autonomy of schools [42]. The new documents focused on pupils' development of transferable skills, such as critical and creative thinking, interpersonal relationships, personal development, and autonomy. Early evaluations of the new system [42] underline the need to support a collaborative culture between teachers to enhance professionalism and ensure consistency between schools. They also call attention to Portugal's extremely low number of young teachers (under 30 years: $2 \%$; over 50 years: $40 \%$ ) and the fact that only 10 percent of teachers perceive their role as valued by society. It is argued that such a situation contributes to a less dynamic profession, which can directly affect the quality of the teaching workforce [42]. Another obstacle identified was the centralized nature of the system, where the government is responsible for 50 percent of management decisions related to education and 80 percent of management decisions related to personnel issues [42]. Such distant decision-making processes affect Portuguese teachers, who currently experience the highest levels of stress in Europe [21]. The source of this stress is mainly the amount of administrative work and pressure from the school's administration. Additionally, studies show that, despite efforts to implement a holistic pedagogy, the primary pedagogical method remains a theoretical explanation of content followed by consolidation exercises [43].

Despite Finland and Portugal's distinct historical backgrounds, their recent landmarks in education converge. Both wish to modernize and adapt their curricula to the current and future needs of a globalized society and make learning a more integrative process. Consequently, it is necessary to investigate the way parent-teacher partnerships are viewed in both countries.

\subsection{The Role of Finnish and Portuguese Parents in Their Children's Learning}

Teachers in Finland have traditionally enjoyed high levels of trust as professionals in all segments of society, including among their students' families. Cooperation with families and other community stakeholders has long been common practice and a key feature of the entire social welfare system. In the latest curriculum reform process, which lasted two and a half years, the Finnish authorities maintained open channels of communication with the community. Indeed, more than 4000 comments on the curriculum were received from organizations and individuals [44]. Additionally, only four percent of Finnish schools reported being subjected to constant pressure from parents, compared to much higher levels in other countries (e.g., Singapore, 60\%; Australia, 36\%) [35].

Finnish parents consider partnership with teachers a shared responsibility, essential to children's success along with active parental participation [45]. They tend to view their own and the teacher's responsibilities as complementary and rather independent of each other. Parents describe themselves as being responsible for their children's rearing 
and upbringing, while teachers are seen as playing a predominantly pedagogical role. In addition, parents expect teachers to keep them informed about their children's conduct and behavioral problems at school [45].

Nevertheless, the exchange of information between teachers and parents is not entirely unproblematic. As most such communication occurs via an online platform, Wilma, teachers' written feedback might not always be perceived as encouraging by parents and thus might threaten the development of a successful partnership [46]. Finnish research on teacher education $[22,47]$ demonstrates the importance of providing pre-service teachers with more practical training in cooperating with parents and developing cultural sensitivity in these partnerships, as the number of multicultural families has risen sharply, particularly in Helsinki metropolitan area. Parents from rural areas in Finland are more likely than urban parents to view digital communication as conducive to partnerships with teachers and to interpret online feedback as encouraging [46]. These findings indicate that more knowledge is required to strengthen parent-teacher collaboration, especially in the capitalcity region.

In Portugal, the challenges to the establishment of partnerships are different and stem from a more fundamental level. For example, a school's working environment and conditions may prevent teachers from dedicating themselves to parent-teacher partnerships [21]. Cooperation with parents and other external stakeholders has emerged as one of the top ten needs of newly qualified Portuguese teachers [48].

Furthermore, current research highlights parental difficulties in partnering with teachers and engaging with learning at various levels. For instance, many parents are unable to accept teachers' invitations due to work hour constraints [49]. Parents also perceive that their involvement is limited to attendance at thematic school events [49]. Other studies suggest that visiting the school solely to receive negative feedback about their children or to attend activities with an "audience role" contribute to parents' lack of habit in cultivating school-home relations [50].

Despite these differences, the structures of the Finnish and Portuguese basic education system and current policies are sufficiently similar to allow comparison. Indeed, a recent study on the two nations [51] illuminates how teachers could approach parents' role from a holistic perspective. It demonstrates that Finnish and Portuguese parents refer to relationship- and leisure-based interactions with their children as legitimate forms of engagement with learning more often than they refer to schooling-related activities. Thus, valuable lessons on how to partner with parents and engage them with learning are likely to emerge from comparative exploratory studies between Finland and Portugal.

This study is based on the constructivist approach taken by both the Finnish and the Portuguese new curricula [24,44], according to which children's learning and knowledge are constructed instead of merely assimilated. Similarly, parent-teacher partnerships regarding children's learning are expected to develop in a constructivist manner, where their interaction and communication serve as a basis for shared knowledge and mutual support for the children's holistic development. However, and potentially because the Finnish and Portuguese new curricular guidelines are recent, how such partnerships and parental engagement are actually constructed is yet to be explored. In the Finnish case, various studies sustain a maintained tradition of co-construction of learning and learning environments between school, home, and community, in the educational system $[35,36,44]$. For Portugal, thorough studies regarding the curriculum guidelines and its actualization, beyond OECD studies [42], are still needed. Overall, both countries, and European nations in general, lack scientific evidence on parental engagement practices [23].

The present study explores this issue in the context of elementary school parents. More specifically, it strives to answer the following research question: "How do parents view the role of teachers in supporting parent-teacher partnerships and parental engagement in school in Finland and Portugal?". 


\section{Materials and Methods}

\subsection{Participants}

This study adopted a qualitative approach based on in-depth interviews. We sent invitation e-mails to a set of 50 Finnish parents with fluent English skills who had previously collaborated with the Copernicus project, by answering a mindset survey in 2016 or 2017 [51]. In turn, the Portuguese parents received an invitation from the principal of the respective schools, and those wishing to collaborate enrolled through a hyperlink. All parents who volunteered were interviewed.

The participants $\left(\mathrm{N}_{\text {Finn }}=19 ; \mathrm{N}_{\text {Por }}=9\right)$ were parents of first- to sixth-grade students from each country's capital city area: Helsinki and Lisbon. The parents signed an informed consent form and were previously informed about the interview theme [52].

In Finland, the parents came from two schools located in different socio-economic neighborhoods to ensure diversity of parental experiences and narratives. One school, with 900 students, provided basic education from grades 1 to 9 , while the other, with 940 students, taught grades 1 to 12. Schools in Portugal are organized in groups (agrupamentos) of neighboring schools with complementary levels under the same administration. The Portuguese parents came from one five-school agrupamento of 2550 pupils from kindergarten to grade 12 , that served a heterogeneous neighborhood.

The Finnish parents were interviewed face-to-face in February 2020, whereas the Portuguese were interviewed between March and June 2020 via the videocall software Zoom on account of the coronavirus pandemic. All necessary precautions to ensure the participants' privacy during the interviews were taken. The Finnish and Portuguese participants were interviewed in English and Portuguese, respectively.

The parents' mean age was 44 years $\left(\mathrm{M}_{\text {Finn }}=47 ; \mathrm{SD}_{\text {Finn }}=9 ; \operatorname{Min}_{\text {Finn }}=40 ; \operatorname{Max}\right.$ Finn $=70$; $\mathrm{M}_{\text {Port }}=40 ; \mathrm{SD}_{\text {Port }}=6 ;$ Min $_{\text {Port }}=29 ;$ Max $\left.{ }_{\text {Port }}=50\right)$. Most participants were female $\left(\mathrm{N}_{\mathrm{F}}=14\right.$; $\mathrm{N}_{\mathrm{M}}=5$ ), and only one Portuguese mother, among all the parents, lacked a university degree. Ten participants were parents of first to fourth graders $\left(\mathrm{N}_{\text {Finn }}=3 ; \mathrm{N}_{\text {Port }}=7\right)$, and nine had children attending grades 5 or $6\left(\mathrm{~N}_{\text {Finn }}=7 ; \mathrm{N}_{\text {Port }}=2\right)$. Three parents had an only child $\left(\mathrm{N}_{\text {Finn }}=2 ; \mathrm{N}_{\text {Port }}=1\right)$, ten had two children $\left(\mathrm{N}_{\text {Finn }}=3 ; \mathrm{N}_{\text {Port }}=7\right)$, and six had three children $\left(\mathrm{N}_{\text {Finn }}=5 ; \mathrm{N}_{\text {Port }}=1\right)$. Of the 19 parents, two indicated facing major learning and/or behavioral struggles in their children's learning process $\left(\mathrm{N}_{\text {Finn }}=1 ; \mathrm{N}_{\text {Port }}=1\right)$, and another four referred to dealing with eventual or minor struggles $\left(\mathrm{N}_{\text {Finn }}=3 ; \mathrm{N}_{\text {Port }}=1\right)$. All other parents described their children's learning process as good or excellent $\left(\mathrm{N}_{\text {Finn }}=6\right.$; $\mathrm{N}_{\text {Port }}=7$ ).

\subsection{Procedure}

This study's data is drawn from a broader qualitative study on parent-teacher partnerships and parental engagement. We used semi-structured interview protocol to ensure consistency, while also allowing for spontaneous narratives to emerge [53]. The interviewees were asked to speak rather freely about the topics of parental engagement with their children's learning at home and at school, including their children's challenges and successes in learning and the parent-teacher learning-related partnership. The opening question was "Please, tell me about which components, in your opinion, contribute to a successful parent-teacher partnership?" The narratives were followed by clarifying questions by the researcher, who would lead the conversation to the subsequent topic of discussion in a natural manner. Examples of such questions were "What does parental engagement with learning mean from your point of view?", "How can parents engage with learning at school?", and "How can teachers support parental engagement with learning?" The sequence of questions varied from one interview to another to promote flow and spontaneity.

The interviews varied in length from 30 to $120 \mathrm{~min}$, the average length being one hour. They were audio-recorded and later transcribed, generating 213 pages of text. Before the interview, the parents also completed a short demographic questionnaire. 


\subsection{Analysis}

Inductive content-analysis was employed to study the data. We chose this approach because it is commonly used in research aimed at enhancing understanding of and retrieving meaning from rich verbal data in an objective and systematic manner [54]. Thus, all the codes were derived from the data [55]. The unit of analysis varied from parts of sentences to whole paragraphs, the criterion for inclusion being that each coded excerpt constituted an independent element of meaning about the phenomenon [55]. The analysis was performed using Atlas.ti 8 software.

After the unit of analysis was established, the next step was to codify the data, to identify parents' perspectives on the role of teachers in partnerships and engagement. This began with the first author coding each interview. Every time a new topic on the role of teachers emerged, a new code was created. The codes were clustered into eight subcategories and later into three main categories. Then, the second author coded the interviews independently according to a shared codebook previously developed between the authors. Cohen's kappa values were calculated using SPSS 27 software to ensure inter-rater agreement regarding the main categories. The kappa values for the first, second, and third main categories were, respectively, $0.767,0.877$, and 0.748 , showing a high level of agreement. Lastly, disagreements were discussed and the items in questions were jointly recoded. This process necessitated iterative analyses of the data. Example 1 demonstrates a unit of analysis related to communication, of which the code was providing open channels of communication, subcategory teacher dialogues, and main category teacher communicates.

Example 1: He [the teacher] likes the presence of the parents. He is always telling us 'If you have any questions, even regarding some content of study, or some other question, no problem, just call me, I am always available. I gave you my phone number and you also have my Facebook [profile], you can always send me a message, there's no problem whatsoever'. So, he ended up making us [parents] very comfortable and opened up the door widely for that. (Parent 6)

\section{Results}

The results are grouped under three main themes that correspond to the perspectives of parents about the role of teachers in partnership and parental engagement. The themes were (1) the teachers communicate, (2) the teachers show professionalism, and (3) the teachers invite active participation. Table 2 shows the frequencies of these categories and their subcategories in our data. The results are presented both from a general and a culture-specific perspective.

Table 2. Frequencies of the main categories and subcategories of parents' perspectives on the role of teachers in parentteacher partnership and parental engagement in the school.

\begin{tabular}{|c|c|c|c|}
\hline \multirow{2}{*}{$\begin{array}{l}\text { The Teachers Support Partnership and } \\
\text { Parental Engagement When They }\end{array}$} & \multicolumn{3}{|c|}{ Number of Statements } \\
\hline & $\begin{array}{c}\text { Finnish }(\mathbf{N}=10) \\
f\end{array}$ & $\begin{array}{l}\text { Portuguese }(\mathbf{N}=9) \\
f f\end{array}$ & $\begin{array}{c}\text { Total }(\mathbf{N}=19) \\
f\end{array}$ \\
\hline Communicate & 76 & 59 & 135 \\
\hline Dialogue & 42 & 34 & 76 \\
\hline Inform & 26 & 12 & 38 \\
\hline Give pedagogical advice & 7 & 4 & 11 \\
\hline Welcome parents' initiatives & 1 & 9 & 10 \\
\hline Show professionalism & 44 & 24 & 68 \\
\hline Have competence to teach & 38 & 17 & 55 \\
\hline Have a good pedagogical relationship with the child & 6 & 7 & 13 \\
\hline Invite active participation & 27 & 28 & 55 \\
\hline Invite to parental activities & 15 & 26 & 41 \\
\hline Invite to collaborative activities & 12 & 2 & 14 \\
\hline Total of statements & 147 & 111 & 258 \\
\hline
\end{tabular}




\subsection{Teachers Communicate}

One pattern that emerged from the data was the importance parents placed on communication. Teachers' ability to communicate seemed to be perceived as a major boon to parental engagement and a basic element for successful parent-teacher partnerships. Such communication may take different forms. The most frequent form within our data was teachers' ability to engage in dialogue, i.e., to establish two-way communication that provides space for parents' input and possible insecurities. This mother's statement well illustrates such an ability in the form of a "no-barrier" attitude:

The most important component is smooth communication and no barrier. Because if you don't have a barrier, you can also approach the teacher with some problematic issues, or ask for advice. ... We are all emotional beings, and we see things in a different way, so it is important to communicate, to speak things out and to be understood. (Parent 18, Finnish, Female, 44 years old)

Additionally, of great relevance to parents was the need to be kept informed by the teacher. The parents seemed to perceive such teacher behavior as the most reliable way of monitoring their children outside the home. Nevertheless, the Finnish and Portuguese parents shared different narratives of being informed. The Portuguese parents focused more on the "remedial" role of information, such as being informed of problems or homework matters, while the Finns emphasized the importance of receiving regular information about their children's schooling. This information arrived in the form of weekly letters sent by teachers to all parents about the classroom routine of the past week and plans for the following week through the Wilma online platform. For example, one mother stated:

It is very important information to me, because my son doesn't speak so much. I ask him how the day was, and [he answers] "it was good". I am left wondering about what is happening in real life, because I can't be there watching what's happening, so it's the only way to get the information. I like to get these emails. (Parent 10, Finnish, Female, 54 years old)

The communication the parents valued from teachers also came in the form of providing pedagogical advice and welcoming parents' initiatives. The former refers to specific recommendations, such as suggestions for supporting children's study at home or for visiting a certain museum exhibition. The latter relates to the establishment of a communication channel that accepts and welcomes parents' ideas and interventions at the school. Being welcomed by teachers was mentioned by almost all the Portuguese parents. These parents referred to the importance of feeling that the "school's door" was open to them, that teacher-parent face-to-face interactions were not only for exceptional circumstances, and that the teacher was able to convey that message, from the beginning.

Overall, the parents perceived parent-teacher communication as a fundamental element of parent-teacher partnerships and parental engagement. This communication encompassed both parents actively reaching out to the teacher, and teachers taking the initiative to inform, support, or reach out to parents.

\subsection{Teachers Show Professionalism}

The parents perceived showing professionalism as a key factor in their partnership and engagement. Teachers' professional competence and ability to maintain a good pedagogical relationship with students emerged as manifestations of being professional.

The parents perceived teachers as competent professionals when they noticed their children were achieving the expected learning goals and when the teacher succeeded in creating a positive classroom atmosphere, showed motivation, creativity, and dedication to teach, and responded effectively to problems such as bullying. The parents often framed the teacher's professionalism within the context of the school as an institution, revealing that they viewed this professionalism as dependent on the teachers' intrinsic and extrinsic factors. The Finnish and Portuguese parents addressed these teacher characteristics similarly in their narratives, although the Finns mentioned them more often. 
The teacher-child relationship was perceived by both Finnish and Portuguese parents as a central aspect of the teacher's competence that influenced parent-teacher partnerships and parental engagement. The parents referred to the importance of feeling that their children liked their teacher, and vice-versa, and that the child was supported, encouraged, and protected by the teacher at school. The parents clearly perceived the child-teacher relationship as one of the main preconditions for an effective parent-teacher partnership. The parents also mentioned the possibility of continuous interaction over time as an important factor in the development of a good relationship between the teacher and the child and consequently with the parent. The statement below summarizes these findings:

It is also the motivation you can see in the teacher, how dedicated they are to the class. Like, how often they change a group or school. Sometimes, if there's some trouble for the school to have a motivated teacher stay with the group for a long time, you can see that they change the teacher every half a year. But, sometimes, you have a teacher that stays for many years, and it makes a big difference to get to know the teacher. Also, that they have a long period of time with your child, so they get to know them personally and see the growth, and also have an effect on their learning skills, and if there's some problems, they can address them and see the results. (Parent 14, Finnish, Male, 43 years old)

Contrary to the previous point on teachers' ability to communicate, this pattern in the parents' narratives does not directly reflect teacher-parent interactions. Instead, it demonstrates that even when parents and teachers are not in direct contact, their relationships continue to develop while mediated by other elements. This indicates the importance of the quality of both the teaching and the pedagogical teacher-child relationship.

\subsection{Teachers Invite Active Participation}

A third central aspect in the parents' narratives was teachers' invitations of active parental participation. The parents were specifically asked about school-related engagement. Thus, it is natural that participation emerged consistently as a theme. However, it is here that the Finnish and Portuguese parents' narratives differed the most. First, the Portuguese parents mentioned active participation more often than did the Finnish parents-while the Finns focused more on teachers' communication and professionalism. Second, from the two abovementioned forms of active participation-parental activities and collaborative activities-Finnish parents referred equally to both, whereas the Portuguese focused almost solely on parental activities.

The invitations of active participation that parents considered supportive of parentteacher partnerships and parental engagement were extremely diverse. They included attending fun family days to play sports with teachers and school staff, attending parents' association meetings to organize future events, visiting the classroom to explain their professions to the children or to perform a reading, visiting the school to bake a cake with the children, watching the children perform in a musical event or performing with the children, and supporting a school's project from home by fundraising or sewing accessories for the school's carnival parades.

The Finnish parents illustrated their active participation in parental activities largely by referring to attending parents' association meetings mediated and organized by the teacher, where the parents would arrange the annual spring gathering and some other events. They also mentioned visiting the school to watch their children perform in a musical event-normally, at the spring gathering they had arranged-or to perform with the children, as, for example, in a Finnish-language poetry reading. It was evident from the Finnish parents' narratives that they were unaccustomed to visiting the school premises frequently for parental activities. When they did, these activities were normally intended to encourage parents' participation in the children's learning (e.g., a poetry reading together as part of curriculum realization), or to support parents' social interactions with each other, as stated by this father: 
All the activities where my engagement is bigger is organizing, with other parents, all these activities besides school. It's about social engagement with other parents. The way the teacher has managed that is really good. She took a very big responsibility, kind of drew all the parents in. We have this small group of parents who organize this event in the spring, kevätkeikaus. It's kind of a big event, a lot of parents go there and all different classes that they [the school] have. So, the teacher took care of the responsibility and let us do that, and we just did it. And it's good we have those, because it is not only about having a relationship with the teacher, but socializing, having this relationship with the other parents. (Parent 12, Finnish, male, 41 years old)

In the case of the Portuguese parents, parental activities, common throughout the school year, seemed to create a setting where the school community could gather, relax, and enjoy some time together, i.e., where community interaction could extend beyond schooling matters. Elements of the child-parent relationship were also present in the Portuguese parents' statements, although less frequently. Moreover, despite perceiving parental activities as supportive of partnerships and parental engagement, the Portuguese parents also seemed to view them as somewhat of a burden, given that the school day finished at around five o'clock and most parents' working day ended around the same time or later. This is indicated in the following statement from a mother:

Of course, it is very nice to gather together and to know each other and to go there [to the school] to do something, to play.... That "family day" where we were all together, with the teacher, with all the children.... Well, yeah, two or three times a year I think is enough. As long as, in the background, there is continuous interaction, and communication and team work [with the teacher]." (Parent 4, Portuguese, Female, 40 years old)

Collaborative teacher-parent activities were seldom mentioned by the Portuguese parents as a form of school-related active participation. The exceptions were two statements about the importance of being invited to less rigid school projects that allowed parents' creativity in their participation and of being invited to face-to-face meetings with the teacher. By contrast, face-to-face meetings with the teacher were very frequently mentioned by the Finnish parents as a form of school-related collaborative active participation that legitimated the parents' role. Even though the Finns reported attending such meetings only once or twice a year-given that most of the interaction occurred online- they referred to these as key moments not only for the partnership between parents and teachers but also between parents, teachers, and children. They also remarked on their satisfaction with this pattern of interaction. As one father explains:

This meeting is only with the child and the teacher, concerning the kid, where teachers usually have some documents that parents filled in, where they asked questions about how we feel about how the schooling is going. And we can help with that document. We talk with the child, go through how the progress is going, and then we give the papers to the teacher before (the meeting). And we talk with the teacher if they agree, if there's some issue, things the child studied that are too easy or too difficult, that they can try to adjust or think of how to make it better. And also, for us, it's good for us to know if the child is keeping up, because the amount of learning is quite a lot.... Often I think children have some subjects they don't like so much and they might not learn as quickly as they should, and we can discuss those things with the teacher on that meeting. (Parent 14, Finnish, Male, 43 years old)

In general, the parents' school-related active participation occurred in both parental activities and collaborative activities with the teacher. However, distinct differences between Finnish and Portuguese in-school participation were evident. In the Portuguese context, teachers tended to invite parents to participate in activities throughout the school year-activities which were often unconnected to the children's learning goals and that 
may be demotivating to parents after a long day at work. In the Finnish context, teachers invited parents to specific collaborative goal-oriented occasions regarding the children's learning progress and future-occasions where not only the parents but also the children participated.

\section{Discussion}

In this article, we set out to explore parents' views on teacher support for parentteacher partnerships and parental engagement from a qualitative standpoint. We also looked further into differences and similarities between Finnish and Portuguese parents' narratives. Here, we followed Janet Goodall's framework of parental engagement and parent-teacher partnerships. We analyzed, by means of inductive content analysis, individual interviews of 19 parents of elementary school children.

In this study, we identified several attributes, within the role of teachers, that were perceived by parents as supportive of a successful parent-teacher partnership and of parental engagement with the school. In particular, these attributes concerned teachers' ability to communicate, to show professionalism, and to invite active participation in the school. Our findings align with previous research that demonstrates the importance parents place on parent-teacher communication $[12,13]$ and teachers' ability to engage in dialogue [14-16] for the development of partnerships and parental engagement. Our results also confirm previous research showing the positive impact of meaningful invitations on role construction and parental motivation to engage with their children's schooling [4,17]. Additionally, the present findings, along with our previous research on parental engagement in the home [51], demonstrate the applicability of Goodall's framework of parental engagement and parent-teacher partnership. In the holistic pedagogical contexts of our participants, all the components of this framework contributed to successful partnerships and engagement: dialogue, legitimation of parents' role, and invitations to meaningful participation [1,11]. In this study, these factors were revealed in the form of teachers' communication, professionalism, and invitations to active participation.

Within these categories, the parents' narratives nevertheless revealed country-specific differences, likely embedded in their historical and cultural backgrounds. Despite identifying similar ways of perceiving teacher support, the parents' descriptions often differed, both in frequency and in meaning. The Finnish parents' perspectives formed a picture of parent-teacher partnerships and engagement with the school grounded in little face-to-face contact but consistent communication. This pattern aligns with previous research, as the simplicity and relative infrequency of parent-teacher interactions seem to be supported by the parents' view that their responsibilities and those of the teachers are complementary but independent, and that home and school are perceived as serving different purposes [45]. Their sense of teachers' professionalism is gleaned through weekly letters via Wilma and annual or biannual meetings, as well as through their children's achievement and wellbeing. This means of communicating with the teacher was viewed positively by our urban Finnish parents. Thus, this finding has partially contradicted previous research indicating that rural parents are more likely than urban parents to perceive digital communication with the teacher as conducive to partnerships [46]. In this study, the Finnish parents indicated that regular Wilma messages helped not only to keep them informed about their children and their children's environment but also to create a sense of predictability and flow in parent-teacher communication. Consequently, parents seemed to feel little need for face-to-face encounters with the teacher. According to the parents' narratives, neither they nor the teachers seem to ask "too much" from each other, and all extra requests from teachers were seen as clearly optional or respectfully negotiated. The Finnish parents' narratives conveyed the idea that "less is more" and demonstrated trust in the teacher and the educational system. Traditionally, the professional competence of teachers has been universally recognized by Finnish society and seen as an intrinsic part of becoming a teacher [29,33,35]. Overall, Finns exhibit relatively strong trust in the various strands of the social welfare system [28], including public schools and teachers. For Finnish parents, belief 
in teachers' competence to teach and to build a relationship with their children constitutes a strong foundation for parent-teacher partnerships. Our interviews with Finnish parents indicated that trust in teachers' ability to perform their work exceptionally well seemed to enable both effective communication and active parental collaborative participation.

Our Portuguese parents', by contrast, expressed more complex perspectives on their partnerships and school-related engagement. The parents' narratives revealed a conceptualization of partnerships and engagement grounded in rather frequent-and largely face-to-face-parent-teacher interaction. Moreover, the responsibility for building this partnership seemed to rest heavily with teachers, specifically in their invitations for participation in recreational activities. In general, the parents reported enjoying visits to their children's school space and contact with teachers in a more informal setting. This finding contradicts previous research suggesting that Portuguese parents feel they are invited to school primarily to receive negative feedback about their children [50]. Nevertheless, the parents in our study sometimes found it challenging to fit parental school activities into their busy and long working hours. These findings are in line with those of Bento et al. [49]. In addition, the parents conveyed the idea that some school-related activities, mainly those where they played the role of spectator, were unmotivating, which confirms previous research findings [50]. Like their Finnish counterparts, the Portuguese parents perceived the idea of simplicity in parent-teacher partnerships and parental engagement as supportive and valued continuous communication over sporadic interaction. Nonetheless, these were not seen as common features of the present Portuguese system. Beyond visits to the school, parent-teacher communication varied widely, i.e., it differed from parent to parent in the same school or classroom. This can be partially explained by the current context of the Portuguese educational system, where teachers are highly stressed, must dedicate a large amount of time to administrative work, and are obligated to implement curriculum changes decided by central government [21,42]. Such time constraints can also be the reason parents perceived their communication with teachers as focusing primarily on problems to be solved. On the other hand, according to the parents' narratives, it was just these challenging situations that brought teachers and parents closer together. The parents described teachers as being responsive to their requests for help and advice, which played a major role in their partnership, as they felt that teachers were willing to meet them as often as necessary. In a challenging context where teachers' schedules can be chaotic, teachers' readiness to find time to invite parents to the school and listen to their concerns earned the sincere appreciation of parents. Such findings align with previous research $[14,15]$ about the importance of teachers' time dedication to parents in building their partnerships.

Overall, despite the Portuguese context presenting a more challenging setting for parent-teacher partnerships, this study provides exemplar practices for cultivating effective partnerships and engaging parents in school in both countries. In Finland, such practices include regular communication, which can be supported by digital tools, as well as one or two meetings oriented to discussing students' learning milestones-respecting the schedules of both parents and teachers. In Portugal, these practices involve responding to and providing space for parents' requests for face-to-face meetings, which enable real-time dialogue and the development of proximity between teachers and parents.

This study provides detailed descriptions of the way parents perceive and experience teachers' support for partnership and engagement. The current demands in education can cause future teachers to experience insecurity about their own abilities to partner with parents and engage them in learning [20,22]. Our results help to inform the implementation of a holistic pedagogy coherent with the Finnish and Portuguese new curricular goals $[24,25]$ by presenting concrete samples of teacher's practices in parent-teacher partnerships. Moreover, they help dispel the recurrent belief that dealing with families is highly challenging. 
Two key findings of this study could serve to guide early career teachers' interaction with parents. The first is the central importance of keeping parents informed. Weekly information from the teacher about their children group's accomplishments, routine, and planned activities establishes a predictable rhythm to the communication and is apt to make parents feel engaged and considered. Such information may be short and simple, but it nevertheless establishes an important dynamic where parents perceive they are part of their children's education - even when this occurs online. The second, regarding invitations of active participation, is the importance of inviting parents to cooperative and periodical events at the school, instead of inviting to recurrent, parents-only activities. Invitations to cooperation at the school could focus on goal-oriented tasks directly related to the student's progress. In addition, one or two recreational activities a year can support the improvement of the parent-teacher partnership and the building of a sense of community within the school. Such activities, focused more on parents than on parent-teacher cooperation, might be more likely to support the partnership when they have a meaningful purpose, e.g., are connected to the curriculum aims. Above all, it is necessary to maintain an open channel for dialogue and to listen to parents' requests, as they are likely to differ from person to person.

This study nevertheless contains limitations concerning the background of our participants. It is important to acknowledge that, with the exception of one parent, all participants had a university degree. Thus, the sample was insufficiently heterogeneous to ensure the generalizability of the findings. Consequently, our results must be interpreted within the context of highly educated parents. Additionally, among our participants, two Portuguese parents had children attending grades 5 and 6 . This constitutes a limitation because the structure of teaching in these grades differs between Finland and Portugal. In Portugal, starting in grade 5, pupils are taught by a variety of subject teachers, and they begin to have a more compartmentalized timetable, which poses additional challenges to partnerships and parental engagement. In terms of methodology, one limitation of our individual indepth thematic interviews was that the Finnish parents were not interviewed in their native language. Although all the parents spoke English fluently, some were more comfortable than others with talking in a foreign language, which may have prevented them from exploring some interview topics more deeply. It is also important to refer that differently posed interview questions could have originated different findings, as we aimed to explore best practices and therefore focused our questions on successful partnerships. Nonetheless, despite its limitations and constraints, this study possesses considerable strengths, such as a qualitative design that provides rich descriptions of the participants' experiences and meaning-making in their own words. Such individualization is one of the most salient advantages of conducting qualitative research [55]. Even though we recognize the nongeneralization of the results from a cross-cultural standpoint, we believe that both general and cultural-specific findings shed new light and bring forward relevant insights regarding parental engagement in school and parent-teacher partnerships to Finnish, Portuguese, and other holistic educational systems.

We recommend that future studies on this topic explore more diverse settings, interviewing parents from immigrant backgrounds and various socio-economic groups. In addition, it would be important to describe teachers' perspectives on the same topics.

Author Contributions: Conceptualization, C.L., E.K., K.T.; methodology, C.L., E.K., K.T.; software, C.L.; validation, E.K.; formal analysis, C.L., E.K.; writing - original draft, C.L.; writing-review and editing, E.K., K.T.; supervision, E.K., K.T.; project administration, K.T.; funding acquisition, C.L., E.K., K.T. All authors have read and agreed to the published version of the manuscript.

Funding: This research was funded the Finnish Agency for Education (EDUFI: TM-19-11247).

Institutional Review Board Statement: The study was conducted according to the guidelines of The Finnish Advisory Board on Research Integrity.

Informed Consent Statement: Informed consent was obtained from all subjects involved in the study. 
Data Availability Statement: The raw data supporting the conclusions of this article will be made available by the authors upon request.

Conflicts of Interest: The authors declare no conflict of interest.

\section{References}

1. Goodall, J. Learning-centred parental engagement: Freire reimagined. Educ. Rev. 2018, 70, 603-621. [CrossRef]

2. Stroetinga, M.; Leeman, Y.; Veugelers, W. Primary school teachers' collaboration with parents on upbringing: A review of the empirical literature. Educ. Rev. 2019, 71, 650-667. [CrossRef]

3. Cankar, F.; Deutsch, T.; Kolar, M. Teachers and parents-partners with different expectations. Int. J. Parents Educ. 2009, 3, 15-28.

4. Deslandes, R.; Rousseau, N. Congruence between teachers' and parents' role construction and expectations about their involvement in homework. Int. J. Parents Educ. 2007, 1, 108-116.

5. OECD. The Future of Education and Skills: Education 2030. Available online: http://www.oecd.org/education/2030/E203 OPositionPaper(05.04.2018).pdf (accessed on 2 March 2021).

6. Epstein, J. School, Family and Community Partnerships-Preparing Educators and Improving Schools; Westview Press: Boulder, CO, USA, 2011.

7. Hoover-Dempsey, K.V.; Walker, J.M.T.; Sandler, H.M.; Whetsel, D.; Green, C.L.; Wilkins, A.S.; Closson, K. Why do parents become involved? Research findings and implications. Elem. Sch. J. Miedel Reynolds 1999, 106. [CrossRef]

8. Levinthal, C.; Kuusisto, E. Parental engagement in children's learning: A holistic approach to teacher-parents' partnerships. In Pedagogy in Basic and Higher Education: Current Developments and Challenges; Tirri, K.M., Toom, A., Eds.; IntechOpen: London, UK, 2020; pp. 203-219. [CrossRef]

9. Epstein, J.L. School, family, and community partnerships in teachers' professional work. J. Educ. Teach. 2018, 44, 397-406. [CrossRef]

10. Goodall, J. Parental engagement to support children's learning: A six point model. Sch. Leadersh. Manag. 2013, 33, 133-150. [CrossRef]

11. Goodall, J.; Montgomery, C. Parental involvement to parental engagement: A continuum. Educ. Rev. 2014, 66, 399-410. [CrossRef]

12. White, C.P.; Levers, L.L. Parent-teacher engagement during child-centered pedagogical change in elementary school. Child. Sch. 2017, 39, 15-23. [CrossRef]

13. Adams, K.S.; Christenson, S.L. Trust and the family-school relationship examination of parent-teacher differences in elementary and secondary grades. J. Sch. Psychol. 2000, 38, 477-497. [CrossRef]

14. Baker, A. Improving parent involvement programs and practice: A qualitative study of parent perceptions. Sch. Community J. 1997, 7, 9-35.

15. Baker, T.; Wise, J.; Kelley, G.; Skiba, R. Identifying barriers: Creating solutions to improve family engagement. Sch. Community J. 2016, 26, 161-184.

16. McNaughton, D.; Hamlin, D.; McCarthy, J.; Head-Reeves, D.; Schreiner, M. Learning to listen: Teaching an active listening strategy to preservice education professionals. Top. Early Child. Spec. Educ. 2008, 27, 223-231. [CrossRef]

17. Whitaker, M.; Hoover-Dempsey, K. School influences on parents' role beliefs. Elem. Sch. J. 2013, 114, 73-99. [CrossRef]

18. Moroni, S.; Dumont, H.; Trautwein, U.; Niggli, A.; Baeriswyl, F. The need to distinguish between quantity and quality in research on parental involvement: The example of parental help with homework. J. Educ. Res. 2015, 108, 417-431. [CrossRef]

19. Leenders, H.; Jong, J.; Monfrance, M.; Haelermans, C. Building strong parent-teacher relationships in primary education: The challenge of two-way communication. Camb. J. Educ. 2019, 49, 519-533. [CrossRef]

20. Meehan, C.; Meehan, P.J. Trainee teachers' perceptions about parent partnerships: Are parents partners? Early Child Dev. Care 2018, 188, 1750-1763. [CrossRef]

21. Eurydice/European Commission/EACEA. Teachers in Europe: Careers, Development and Well-Being; Eurydice Report; Publications Office of the European Union: Luxembourg, Luxembourg, 2021. [CrossRef]

22. Alanko, A. Preparing pre-service teachers for home-school cooperation: Exploring Finnish teacher education programmes. J. Educ. Teach. 2018, 44, 321-332. [CrossRef]

23. Thompson, I.; Willemse, M.; Mutton, T.; Burn, K.; De Bruïne, E. Teacher education and family-school partnerships in different contexts: A cross country analysis of national teacher education frameworks across a range of European countries. J. Educ. Teach. 2018, 44, 258-277. [CrossRef]

24. Direção-Geral de Ensino (DGE). Perfil dos Alunos à Saída da Escolaridade Obrigatória. 2017. Available online: https:/ /dge.mec. pt/sites/default/files/Curriculo/Projeto_Autonomia_e_Flexibilidade/perfil_dos_alunos.pdf (accessed on 10 February 2021).

25. Finnish National Board of Education (FNBE). National Core Curriculum for Basic Education 2014; Finnish National Board of Education Publications: Helsinki, Finland, 2016.

26. Campos, B.P.; Menezes, I. Personal and social education in Portugal. J. Moral Educ. 1996, 25, 343-357. [CrossRef]

27. Sinnemäki, K.; Nelson, R.; Portman, A.; Tilli, J. The legacy of lutheranism in a secular nordic society: An introduction. In On the Legacy of Lutheranism in Finland: Societal Perspectives; Sinnemäki, K., Portman, A., Tilli, J., Nelson, R.H., Eds.; Finnish Literature Society: Helsinki, Finland, 2019; pp. 9-36. 
28. Niemi, H.; Sinnemäki, K. The role of lutheran values in the success of the Finnish educational system. In On the Legacy of Lutheranism in Finland: Societal Perspectives; Sinnemäki, K., Portman, A., Tilli, J., Nelson, R.H., Eds.; Finnish Literature Society: Helsinki, Finland, 2019; pp. 113-127.

29. Tirri, K. The last 40 years in Finnish teacher education. J. Educ. Teach. 2014, 40, 1-10. [CrossRef]

30. Sarlio-Lähteenkorva, S.; Manninen, M. School meals and nutrition education in Finland. Nutr. Bull. 2010, 35, 172-174. [CrossRef]

31. Mangeloja, E. Religious Revival Movements and The Development of The Twentieth-Century Welfare-State in Finland. In On the Legacy of Lutheranism in Finland: Societal Perspectives; Sinnemäki, K., Portman, A., Tilli, J., Nelson, R.H., Saarikivi, J., Hagman, P., Valaskivi, K., Eds.; Finnish Literature Society: Helsinki, Finland, 2019; pp. 220-236.

32. Statistics Finland. Education in Finland: More Education for More People. 2007. Available online: https://www.stat.fi/tup/ suomi90/marraskuu_en.html (accessed on 20 March 2021).

33. European Commission. Study on Policy Measures to improve the Attractiveness of the Teaching Profession in Europe; Publications Office of the European Union: Luxembourg, Luxembourg, 2013; Volume 2. [CrossRef]

34. Ministry of Culture and Education (MEC). To all 9th Grade Students and Their Parents or Guardians. 2021. Available online: https: / /julkaisut.valtioneuvosto.fi/bitstream/handle/10024/162875/MoEC_compulsory\%20educaton.pdf?sequence=1\& isAllowed $=\mathrm{y}$ (accessed on 12 March 2021).

35. Niemi, H.; Lavonen, J.; Kallioniemi, A.; Toom, A. The role of teachers in the finnish educational system. In The Teacher's Role in the Changing Globalizing World: Resources and Challenges Related to the Professional Work of Teaching; Niemi, H., Toom, A., Lavonen, J., Eds.; Brill Sense: Leiden, The Netherlands, 2018; pp. 47-61. [CrossRef]

36. Lavonen, J. Educating Professional Teachers in Finland through the Continuous Improvement of Teacher Education Programmes. In Contemporary Pedagogies in Teacher Education and Development; Weinberger, Y., Libman, Z., Eds.; IntechOpen: London, UK, 2018; pp. 3-22. [CrossRef]

37. Marôco, J. Portugal: The PISA Effects on Education. In Improving a Country's Education; Crato, N., Ed.; Springer: Cham, Switzerland, 2021. [CrossRef]

38. Sarmento, T. (Re)pensar a interacção escola-família. [(Re)think the school-family interaction]. Rev. Port. Educ. 2005, 18, 53-75.

39. Pintassilgo, J.; Oliveira, H. A formação inicial de professores em Portugal: Reflexões em torno do atual modelo. [Teacher early training in Portugal: Reflections about the current model]. Rev. Contemp. Educ. 2013, 8, 24-40.

40. Sousa-Pereira, F.; Leite, C. Students profile leaving compulsory education, policy and challenges for teacher training. Rev. Educ. Ciência E Cult. 2019, 24, 113-122. [CrossRef]

41. Santos, I. Epistemic work in Portuguese parliamentary education debates: Externalisation to world situations as a source of epistemic capital. Eur. Educ. Res. J. 2021, 1-21. [CrossRef]

42. OECD. Curriculum Flexibility and Autonomy in Portugal-An OECD Review. 2018. Available online: http://www.oecd.org/ education/2030/Curriculum-Flexibility-and-Autonomy-in-Portugal-an-OECD-Review.pdf (accessed on 2 March 2021).

43. Leite, C.; Fernandes, P.C. National curriculum vs curricular contextualisation: Teachers' perspectives. Educ. Stud. 2020, 4, 259-272. [CrossRef]

44. Lähdemäki, J. Case study: The Finnish national curriculum 2016-A co-created national education policy. In Sustainability, Human Well-Being, and the Future of Education; Cook, J., Ed.; Palgrave Macmillan: Cham, Switzerland, 2019. [CrossRef]

45. Böök, M.L.; Perälä-Littunen, S. Responsibility in home-school relations-Finnish parents' views. Child. Soc. 2014, 29, 615-625. [CrossRef]

46. Kuusimäki, A.-M.; Uusitalo-Malmivaara, L.; Tirri, K. Parents' and teachers' views on digital communication in Finland. Educ. Res. Int. 2019, 1-7. [CrossRef]

47. Niemi, H. Teacher professional development in Finland: Towards a more holistic approach. Psychol. Soc. Educ. 2015, 7, 279-294. [CrossRef]

48. Harju, V.; Niemi, H. Newly qualified teachers' needs of support for professional competences in four European countries: Finland, the United Kingdom, Portugal, and Belgium. CEPS J. 2016, 6, 77-100.

49. Bento, A.; Mendes, G.; Pacheco, D. 5th Iberic-American Congress in Qualitative Research. 2016. Available online: http: / / proceedings.ciaiq.org/index.php/ciaiq2016/article/view/648/637 (accessed on 5 March 2021).

50. Sousa, M.; Sarmento, T. Escola-família-comunidade: Uma relação para o sucesso educativo. [School-family-community: A relationship for the educational success]. Gestão E Desenvolvimento 2010, 17, 141-156. [CrossRef]

51. Levinthal, C.; Kuusisto, E.; Tirri, K. How Finnish and Portuguese parents' implicit beliefs actualize at home. Front. Educ. 2021, 6, 1-15. [CrossRef]

52. Finnish Advisory Board on Research Integrity. Ethical Principles of Research in the Humanities and Social and Behavioural Sciences and Proposals for Ethical Review. 2009. Available online: https://www.tenk.fi/en/ethical-review-in-human-sciences (accessed on 10 February 2021).

53. Legard, R.; Keegan, J.; Ward, K. In-depth Interviews. In Qualitative Research Practice; Richie, J., Lewis, J., Eds.; Sage: London, UK, 2003; pp. 139-168.

54. Krippendorf, K. Reliability in content analysis: Some common misconceptions and recommendations. Hum. Commun. Res. 2004, 30, 411-433. [CrossRef]

55. Elo, S.; Kyngäs, H. The qualitative content analysis process. J. Adv. Nurs. 2008, 62, 107-115. [CrossRef] 